\title{
Panel on: The Creation and Distortion of Communication through Information Technology
}

\section{Can You Say That? Communication Contours of Cybersmear}

\author{
Mary Elizabeth Bezanson \\ University of Minnesota, Morris, MN, USA \\ bezansme@mrs.umn.edu
}

\begin{abstract}
New technology asks members of society to reorder their thinking about their world. The deep penetration of new informing technologies in the Internet age invites people to reconsider their conceptions of language, bias, and communication. This paper establishes the contours of communication in cybersmear. Focusing on the character of messages, this paper considers the implications of emotive language on the personal acceptance and legal protection for speech in cyberspace.
\end{abstract}

Keywo rds: cybersmear, language, defamation, emotive, legal, bias, U.S. Supreme Court

\section{Introduction}

Images of the Wild West have colored the American experience for generations. These images have now seeped into the cultural understanding of other nations. The mythic construction of the story begins with the joy of freedom without constraint, moves to the fear of lawless, and ends with resignation as the participants realize that order is necessary. In some ways, since its inception, cyberspace has been the American Wild West especially in chat rooms, bulletin boards, and some Internet sites. Many have felt free to participate with joyous abandon saying anything they liked, knowing their true identities were protected by anonymity. In the mid 1990's, the fear of lawlessness developed as corporations began to seriously pursue those they found to be practitioners of cybersmear. Some clearly wanted the sheriff to come to town. And he did. The problem remained that the judge only visited once in a while. To combat cybersmear, lawyers began to go to court and ask that Internet Service Providers (ISPs) disclose the identities of those making cybersmear posts.

Cybersmear cases are complicated because once the identity of the poster, or speaker, becomes known the case often evaporates because the speaker is silenced. The contention of this paper is that rather than focusing on the identity of the speaker, the courts should focus on the accurate characterization of the message. Due to issues of accessibility, and enveloping nature of United States legal thinking, this paper closely focuses on the U.S. experience of cybersmear. Specifically, this paper will consider a definition of cybersmear, the content of messages considered to be examples of cybersmear, the U.S. Supreme Court's approach to emotive language, concluding with recommendations for the treatment of cybers-

Material published as part of these proceedings, either on-line or in print, is copyrighted by Informing Science. Permission to make digital or paper copy of part or all of these works for personal or classroom use is granted without fee provided that the copies are not made or distributed for profit or commercial advantage AND that copies 1) bear this notice in full and 2) give the full citation on the first page. It is permissible to abstract these works so long as credit is given. To copy in all other cases or to republish or to post on a server or to redistribute to lists requires specific permission from the publisher at Publisher@InformingScience.org mear world wide and the appropriate response to "bias" inherent in all emotive language.

\section{Definition of Cybersmear}

Perhaps not surprisingly, definitions often reveal bias. This is certainly true of the promulgated definitions of "cybersmear." John Swartz, a staff writer for the San Francisco Chronicle, defined 
cybersmear as, "a practice in which individuals post malicious messages about businesses in online forums, to manipulate the stock or to hurt a company they have a grievance against" (1999). There is an important difference in the definition that Blake A. Bell (1999) offered, "The 'corporate cybersmear'in which a false and disparaging rumor about a company, its management or its stock is posted to the Internet ...." Of crucial importance is Bell's addition of "false" to the definition. As Greg Abbot, Attorney-at-Law, (n.d.) noted, "Defamation allows recovery for unfair damage to reputation. As a consequence, if true statements are made about a person that damage their reputation, they cannot maintain a lawsuit." Abbott correctly noted that "truth" as a characteristic of the message has been important only recently. He commented,

One origin of libel and slander laws was a criminal cause of action by the English Crown used to silence its critics; hence, it was the truth of the alleged libel which provoked the lawsuit. However, as the right of free speech developed and gained support, the use of defamation to suppress true statements was rejected. Virtually all states today apparently require that the alleged defamatory statements be false before a defamation action may proceed. (n.d.)

In the United States, truth functions as an absolute defense against defamation. Cybersmear cases are brought as actions against defamation. But the "truth-falsity" dichotomy does not resolve most cybersmear cases because of the emotive function of most language.

\section{Content of Messages}

We now examine the content of actual messages in a set of exemplar cybersmear complaints and cases. For those conducting close contextual analyses of cybersmear cases, vague references to "criticizing the CEO" are not terribly helpful. The content of actual messages is rather difficult to locate since most of cybersmear complaints are resolved before passing through the judicial system.

In one of the few cases to reach a judicial conclusion, the Appellate Division of the Sup erior Court of New Jersey decided Dendrite International, Inc. v. John Doe No. 3 (2001) involving the anonymous posting of a variety of negative messages on the Yahoo! Dendrite message board. Because of the importance of context to the meaning of any me ssage, the court provides some background Dendrite's change in treatment of licensing fees. This change sparked comment in the print and Internet media (p. 762). John Doe No. 3 responded by posting nine comments on the Dendrite board under the pseudonym "xxplrr." The court provided the following comments from John Doe No. 3,

John's [(Dendrite president John Bailye)] got his contract salted away to buy another year of earnings- and note how they're changing revenue recognition accounting to help it.

Bailye has his established contracts structured to provide a nice escalation in revenue. And then he's been changing his revenue-recognition accounting to further boost his earnings (see about 100 posts back).

[Dendrite] signed multi-year deals with built in escalation in their revenue year-over year (pharma cares most about total price of the contract, so they don't care; nor do they care if the price is in software or services). They also have been able to restructure their contracts with Pfizer and Lilly the same way (p. 763).

In the Dendrite case, John Doe No. 3's language was found not to be defamatory since no harm to Dendrite could be connected to his posts (Dendrite International, 2001, p. 772). John Doe No. 3's remarks 
seemed rational given the remarks made by John Doe, later identified as Peter Krum, in HealthSouth Corp. v. Krum.

Krum's posting, described by Lyrissa Barnett Lidsky in her excellent piece "Silencing John Doe" (2000), are of a different tenor. Lidsky described Krum's postings in this way,

There could hardly be a less sympathetic John Doe defendant than Peter Krum (a disgruntled former employee of HealthSouth Corp.) . . . . Posting under the name "I AM DIRK DIGGLER," a reference to the wellendowed porn star in the 1997 movie Boogie Nights, Krum verbally savaged HealthSouth, its CEO Richard Scrushy, and even Scrushy's wife, Leslie, on Yahoo! Finance message board. . . . Krum's postings ranged from relatively innocuous statements about HealthSouth's, "self-serving" management to accusations that Richard Scrushy was "bilking . . . .

[M]edicare reimbursement." The most egregious postings by Krum were those that discussed, in salacious detail, an affair "I AM DIRK DIGGLER" was allegedly having with Leslie Scrushy. Krum, for example, wrote, "I am dirk diggler and I have what [Richard] Scrushy wants. Too bad I keep giving it to his new wife. . . [and] [a]s for those who disapprove of my crowing about sexual liasons [sic] with Dick's wife, lighten up. I am practicing safe sex" (pp. 866-867, citations omitted).

A casual reader notes both the dimensions of truth versus falsity, and rational versus emotive language. One could have proven one as sumes, that Krum was not having an affair with Leslie Scrushy. There remains an unaccounted for difference between the statements, "I am having an affair with Leslie Scrushy" and "I am dirk diggler and I have what Scrushy wants. Too bad I keep giving it to his new wife ...." That difference is between the apparently rational and the moving emotive.

Hitsgalore.com, Inc. v. Shell highlighted most sharply the use of emotive language. Lidsky characterized the language used by John Doe posters in this way,

There, numerous John Does had posted a variety of serious allegations about Hitsgalore.com, Inc. and its officers. The anonymous posters called the corporation a "scam," a "fraud," a "flying turd"; they labeled its officers as "criminals," "crooks," "con men," "slime," and "scum" who had lied to the SEC and duped investors in a "classic pyramid scheme" (p. 933, citations omitted).

Here, the emotive content of the poster's message became obvious. Lidsky proposed that most of these statements were "provable" as true or false (p. 933-934). But the truth or falsity of the statements failed to accurately characterize the nature of the messages posted. The emotive content of the posts carries the anger, frustration, and true feelings of the posters. Emotive language also transmits the bias of the poster.

\section{U.S. Supreme Court Treatment}

We now turn to the United States Supreme Court's treatment of cases involving defamation and emotive language. The Supreme Court of the United States began to consider free speech cases in earnest about 1920. Throughout its history, the Supreme Court has evidenced sensitivity to the importance of emotive language as a feature of messages in protected communication. A few examples will illustrate this sensitivity. In the 1940 decision of Cantwell v. Connecticut, Justice Owen J. Roberts delivered the opinion of the Court determining, 
In the realm of religious faith, and in that of political belief, sharp differences arise. In both fields the tenets of one man may seem the rankest error to his neighbor. To persuade others to his own point of view, the pleader, as we know, at times, resorts to exaggeration, to vilification of men who have been, or are, prominent in church or state, and even to false statement. But the people of this nation have ordained in the light of history, that, in spite of the probability of excesses and abuses, these liberties are, in the long view, essential to enlightened opinion and right conduct on the part of the citizens of a democracy (p. 310).

In Cantwell, a unanimous U.S. Supreme Court realized that individuals will use emotive language in order to persuade others. The Court realized in 1940 that individuals will even resort to false statements in order to be persuasive.

Four years later, in Baumgartner v. United States (1940), Justice Felix Frankfurter wrote for the Court, "one of the prerogatives of American citizenship is the right to criticize public men and measures -- and that means not only informed and responsible criticism but the freedom to speak foolishly and without moderation" (pp. 673-674). The U.S. Supreme Court recognized that protection for freedom of speech required protection for language that was foolish and immoderate.

In the turbulent years of the 1970's, the U.S. Supreme Court considered the constitutional acceptability of repressing a message worn on clothing. Cohen v. California (1971) became the rather infamous case involving the message, "Fuck the Draft," on the back of a jacket. In writing for the majority of the Court, Justice John M. Harlan articulated the view,

Surely the State has no right to cleanse public debate to the point where it is grammatically palatable to the most squeamish among us. . . . For, while the particular four-letter word being litigated here is perhaps more distasteful than most others of its genre, it is nevertheless often true that one man's vulgarity is another's lyric. Indeed, we think it is largely because governmental officials cannot make princ ipled distinctions in this area that the Constitution leaves matters of taste and style so largely to the individual.

Additionally, we cannot overlook the fact, because it is well illustrated by the episode involved here, that much linguistic expression serves a dual communicative function: it conveys not only ideas capable of relatively precise, detached explication, but otherwise inexpressible emotions as well. In fact, words are often chosen as much for their emotive as their cognitive force. We cannot sanction the view that the Constitution, while solicitous of the cognitive content of individual speech, has little or no regard for that emotive function which, practically speaking, may often be the more important element of the overall message sought to be communicated (pp. 25-26).

The United States Supreme Court recognized that the emotive dimensions of messages were often the persuasive spark that captured the communicative intent of the speaker. The Court realized that to deprive speakers and language of that spark was to alter inevitably the message communicated. The Court was then forced to balance the essential emotive quality of language against a well developed recognition that individuals should be protected against defamation. Consequently, the Supreme Court of the United States has examined the implications of hyperbole in balancing free speech claims against defamation assertions. 


\section{Hyperbole}

In two important cases, the U.S. Supreme Court has examined the limitations hyperbole may place on defamation claims: Greenbelt Cooperative Publishing Association v. Bresler (1970) and Old Dominion Branch No. 496, National Association of Letter Carriers v. Austin (1974). Bresler involved a compla int of defamation against a small weekly newspaper, the Greenbelt News Review, for reporting that Bresler's, a local real estate developer, behavior regarding a zoning variance had been "blackmail." The "blackmail" comment was repeated several times in the newspaper with and without quotations, and functioned as a subheading for a news article (p. 7). Bresler filed suit alleging libel since the newspaper knew that he had not been charged with the crime of blackmail (p. 8).

Justice Potter Stewart expressing the view of five members of the Court recognized that there could be no claim of libel against the newspaper since it accurately reported both Bresler's position as well as that of those critical of his behavior (p. 14). Further, Justice Stewart recognized the emotive function of the word "blackmail" in the context of Bresler commenting,

On the contrary, even the most careless reader must have perceived that the word was no more than rhetorical hyperbole, a vigorous epithet used by those who considered Bresler's negotiating position extremely unreasonable. Indeed, the record is completely devoid of evidence that anyone in the city of Greenbelt or anywhere else thought Bresler had been charged with a crime (p. 14).

Justice Stewart recognized that the word "blackmail" in this context was understood by readers to be rhetorical hyperbole and nothing more. Because of this understanding there could be no question of defamation or libel flowing from the accurate reportage of what someone at a meeting said. If one could be so bold, perhaps Justice Stewart understood that a word may not be factually true but could be figuratively true. The figurative, emotive power of language deserved free speech protection.

In Old Dominion Branch No. 496, National Association of Letter Carriers v. Austin (1974), often referred to as National Association of Letter Carriers, the U.S. Supreme Court again considered the connection between rhetorical hyperbole and defamation. National Association of Letter Carriers arose when the union as part of an ongoing attempt to organize all the letter carriers published in their monthly newsletter a "List of Scabs" indicating those letter carriers who had not joined the union and including an extensive and pejorative definition of "scab" attributed to Jack London (p. 267-268). Justice Thurgood Marshall in delivering the opinion of the Court included London's definition,

"The Scab

"After God had finished the rattlesnake, the toad, and the vampire, He had some awful substance left with which He made a scab.

"A scab is a two-legged animal with a corkscrew soul, a water brain, a combination backbone of jelly and glue. Where others have hearts, he carries a tumor of rotten principles.

"When a scab comes down the street, men turn their backs and Angels weep in Heaven, and the Devil shuts the gates of hell to keep him out.

"No man (or woman) has a right to scab so long as there is a pool of water to drown his carcass in, or a rope long enough to hang his body with. Judas was a gentleman compared with a scab. For betraying his Master, he had character enough to hang himself. A scab has not. 
"Esau sold his birthright for a mess of pottage. Judas sold his Savior for thirty pieces of silver. Benedict Arnold sold his country for a promise of a commission in the British Army. The scab sells his birthright, country, his wife, his children and his fellowmen for an unfulfilled promise from his employer.

"Esau was a traitor to himself; Judas was a traitor to his God; Benedict Arnold was a traitor to his country; a SCAB is a traitor to his God, his country, his family and his class." (p. 268, citation omitted, emphasis supplied.)

Of particular concern to those who brought suit was the use of the word, "traitor." Justice Thurgood Marshall commented on that concern, referencing Bresler,

It is similarly impossible to believe that any reader of the Carrier's Corner would have understood the newsletter to be charging the appellees with committing the criminal offense of treason. As in Bresler, Jack London's "definition of a scab" is merely rhetorical hyperbole, a lusty and imaginative expression of the contempt felt by union me mbers towards those who refuse to join (pp. 285-286).

Justice Marshall recognized that the readers, or receivers, of the newsletter would understand that the indicated individuals had been charged with treason. He knew, as we know, that the inclusion of London's definition was an example of rhetorical hyperbole.

Further, Marshall recognized that,

Such words were obviously used here in a loose, figurative sense to demonstrate the union's strong disagreement with the views of those workers who oppose unionization. Expression of such an opinion, even in the most pejorative terms, is protected under federal labor law. Here, too, "there is no such thing as a false idea. However pernicious an opinion may seem, we depend for its correction not on the conscience of judges and juries but on the competition of other ideas." Gertz v. Robert Welch, Inc.(1974) (pp. 339-340).

While the U.S. Supreme Court's adherence to the reasoning of Gertz has lost some strength with the more recent decision of Milkovich v. Lorain, 497 U.S. 1 (1990), Justice Marshall's admonition suggested a path that provides an appropriate balance between hyperbolic, emotive language and defamation suits.

\section{Conclusion}

In summary, the U.S. Supreme Court has recognized the importance of emotive language in the construction of messages and has provided protection for that language. Lower court judges in their treatment of cybersmear have ignored this feature of language in their willingness to compel ISPs to reveal the identity of posters. The solution may well be to consider the effectiveness of the view that the "competition of other ideas" serves as the course of action to correct even "pernicious" opinions.

The Wild West is not so wild anymore. As Lyrissa Barnett Lidsky (2000) suggests, "Indeed, silencing John Doe may be one of the chief motivations behind the new Internet libel actions. Armed with subpoenas, plaintiffs often are able to discover the real identity of the John Doe who has attacked them. ... 
“(p. 881). Without having to prove that "defamation" occurred, corporate America has gained the silence it desired. But silence

does not enhance the process of communication the free speech clause of the First Amendment is designed to support. Judges need to become more sophisticated critics of communication. They need to learn how to look beyond the factual meaning to the figurative meaning. By recognizing the centrality of emotive language to convey a message, the courts would provide fuller protection for communicators on the Internet.

The concern that these communicators will spread bias and misinformation may be well founded. Certainly other media sources have been used for the promulgation of ideas that are perceived by some to be biased. But language, as we have seen, carries with it bias. Even attempts to remove all emotive intensity may promote bias. Arguing that only language that appears to be "rational" rather than "emotive" does not solve the problem. The only solutions are toleration and talk.

By moving in this direction, judges also resolve the tension between emotive language and defamation. Those believing themselves smeared through the Internet can use this same channel in their own defense. As Justice Marshall recognized, through the "competition of ideas" the truth emerges. This competitive model of communication flows through all of Western culture infusing the development of the constitutional democracy of the United States, and flowing into the Internet as it now operates.

If the Internet is not to become one more channel of communication controlled by wealthy media outlets and wealthier corporations, than an individual's access and freedom must be scrupulously protected by public opinion and the judiciary of all nations.

\section{References}

Abbott, G. (n.d.). Basics of Minnesota Defamation law. Retrieved February, 26, 2003 from http://www.abbottlaw.com/defamation.html

Baumgartner v. United States, 322 U.S. 665 (1944).

Bell, B. A. (1999, April 19). Dealing with “Cybersmear.” Simpson, Thacher \& Bartlett. Retrieved January 27, 2003, from http://www.simpsonthacher.com/FSL5CS/articles/articles672.asp

Cantwell v. Connecticut, 310 U.S. 296 (1940).

Cohen v. California, 403 U.S. 15 (1971).

Dendrite International, Inc. v. John Doe No. 3, 775 A.2d 756 (N. J. Super 2001).

Gertz v. Welch, 418 U.S. 323 (1974).

Greenbelt Cooperative Publishing Association v. Bresler, 398 U.S. 6 (1970).

Lidsky, L. B. (2000). Silencing John Doe: Defamation \& Discourse in Cyberspace. Duke Law Journal, 49, 855-946.

Old Dominion Branch No. 496, National Association of Letter Carriers v. Austin, 418 U.S. 264 (1974).

Swartz, J. (1999, April 13). Corporations Fight Internet “Cybersmear.” San Francisco Chronicle. Retrieved February 14, 2003, fromhttp://www.sfgate.com/cgi-bin/article.cgi?file=/chronicle/archive/1999/04/13/BU93359.DTL

\section{Biography}

Mary Elizabeth Bezanson (Ph.D. University of Washington, 1987), Associate Professor of Speech Communication at the University of Minnesota, Morris, works in rhetoric and freedom of speech with a particular interest in the right to receive. Among other major publications, she is the author of The Right to Communicate, Decisions and Dissents: A Supreme Court Reader (Lanham, Maryland: University Press of America, 1994). 